\title{
鋼球肩乗り上げ時の玉軸受寿命予測方法*
}

\author{
長 谷陽 夫*1, 芋 生 明 俊*2

\section{Ball Bearing Fatigue Life Estimation Under the Condition of Contact Ellipse Being Over Shoulder}

\author{
Haruo NAGATANI*3 and Akitoshi IMOU \\ ${ }^{* 3}$ NTN corporation, Automobile Engineering Department, \\ 1578 Higashi-Kaizuka, Iwata-shi, Shizuoka, 438-8510 Japan
}

\begin{abstract}
There are no prediction methods of bearing fatigue life when ball bearing is used under the condition of contact ellipse being over shoulder. To enable this prediction there are two difficulties. The first is contact problem shifts from non-conforming contact problem to conforming contact problem because of large load. The second is there is no practical method for bearing life estimation under the condition like as edge load occurring, though there exist many decision methods about optimal crowning when edge load occurs. For each problem, authors have proposed each solution. Combining those methods, we propose the bearing life ratio estimation method under the condition of contact ellipse being over shoulder. To verify this method, we compare the calculation result with bearing life test result for 50 samples that have different 3 inner ring outer diameters. The both result agree well, therefore the validation of this method was achieved. Ahead of that, we propose improved solution to the first difficulty, and verify the contact pressure and shear stress by comparing FEA result with improved solution when contact ellipse being over shoulder. This solution has been used to estimate above-mentioned bearing life.
\end{abstract}

Key Words : Rolling Bearing, Life Prediction, Fatigue, Design, Contact Problem, Analytical Model, Numerical Analysis, Shear Stress, Rolling Fatigue, Ball Bearing, Contact Ellipse, Conforming Problem

\section{1. ま え がき}

玉軸受の鋼球が肩乗り上げを生じる条件下で使用さ れるとき，その軸受寿命を予測することが設計上必要 になるが,このような場合の寿命予測に関する計算手 法の報告は見当たらず, 肩乗り上げの程度が必要寿命 に対して許容できるレベルか否かの判断は過去の経験 や実験確認によって行っているのが実情である.

肩乗り上げ時の寿命予測を可能にするためには, 克 服すべき問題が二つある。一つは鋼球が肩乗り上げを 生じるような大荷重条件下では, 接触領域が広くなり, 接触だ円が平面上に存在するとはみなせなくなり， Conforming Contact Problem になることである.こ のため, 通常の Non-Conforming Contact Problem (以下 “Contact”を省略する)での数值計算方法(1)で は面圧や表面下せん断応力を計算できず, FEM や BEM を除いて, 計算手法が皆無の状況であり, 寿命 予測より困難になっている，著者らは別報(2)でこの 問題に対する実用的な面圧分布計算方法を提案してお

* 原稿受付 2007 年 12 月 27 日.

*1 正員, NTN (株) 自動車商品本部自動車技術部(昰 438-8510 磐田市東貝塚 1578).

*2 NTN (株) 自動車商品本部自動車技術部.

E-mail : haruo_nagatani@ntn.co.jp
り，この手法を用いれば，肩乗り上げが生じたときの 面圧計算が可能である。

$$
\text { もう一つは, エッジロードが生じたときの適当な軸 }
$$
受寿命予測方法がないことである.ころ軸受では，工 ッジロードを考慮した最適クラウニングの設定方法に 関する報告例はある(3) (5) が，エッジロードが生じた ときの寿命計算方法はほとんど報告されていない. Ioannides ら ${ }^{(6)}$ は表面下の応力から寿命を予測すると いう普遍性のある寿命計算手法を提案しているがエッ ジロードへの適用については触れておらず，また Lundberg-Palmgren ${ }^{(7)}$ の寿命理論(以下「LP 理論」 と呼ぶ）とのかい離が大きいため使いにくい面がある. 著者の一人は別報で表面下せん断応力分布から寿命を 予測する手法を提案し ${ }^{(8)}$, LP 理論との整合性のある 寿命比予測方法の確立を図ってきた。この手法ではエ ッジロードが大きい場合に, 計算寿命がやや大きく算 出されるという問題はあるが, 従来手法ではとらえら れない特性を算出できる。これを鋼球肩乗り上げ問題 へも適用すれば, 肩乗り上げ時の寿命を予測できる可 能性がある。

本報では上記二つの手法を組合わせて, 鋼球肩乗り 上げ時の寿命予測方法を提案し, 実験結果と比較検証 する。また, Conforming Problemに対する文献 (2) 
の手法について改良を加え, 表面下応力の計算をより 簡単・高速にできるように工夫した，なお，文献 $(8)$ では, 高精度化の目的で要素内部に線形な面圧分布を 仮定した要素(9)を使用したが, Conforming Problem に扔ける面圧計算方法は近似手法であることと, 要素 分割を細かくすれば, 波打ち現象はある程度防止でき, 極表層以外のせん断応力值は使用できること，そして 極表層のせん断応力值は小さいため寿命への影響は小 さいこと, を勘案して文献 (2)の手法と同様, 要素内 部の面圧分布は均一であると仮定して進める.

\section{2. 接触面圧計算}

$2 \cdot 1$ 解析概 要 文献 (2)では, Boussinesqの 解(10) をあたかも無限領域全体の解であるかのように 取扱い, ボールと内輪間の接触面圧計算に際して, 図 1，2のように基準面を円筒として解析した.しかし， 影響係数は荷重点近傍で大きく，かつ深さ方向の変形 がいちばん重要であるという考察から，本報では文献 (2) で行ったような 3 方向の影響係数を求めるのでは なく, 平面問題の手法を円筒面への写像のように取扱 う. 以下にこの手法について述べる.

本手法の特徵は, 以下のものである.

（1）メッシュ間距離の算出には，基準円筒面上で の距離を用いる.すなわち,メッシュ間の円筒面周方 向長さと円筒軸方向距離だけを用い, 面に垂直な方向 の距離は無視する.

（2）影響係数算出に当たって円筒面の曲率を考慮 する。

（3） Boussinesq の解の $z$ 方向(無限平面に垂直な 方向)変位のみを用いる.

文献 ( 2 ) に対する変更点は, (1)，（3 項である. また, 通常の Non-Conforming Problem 解法に対す る変更点は (1)，（2）項であるすなわち, NonConforming Problem での解法に対して, 要素間の距

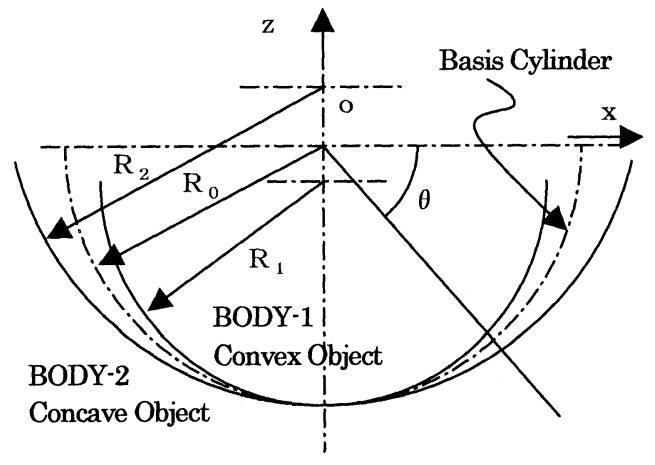

Fig. 1 Contact analysis model
離の算出を (1)の方法とし, 影響係数の算出に( 2 )の 方法を用いるという修正を加えるだけでConforming Problem に対応できる，別の見方をすると，基準円筒 面を展開し, これを平面として取扱う手法ともみなせ る。

以上より, 本手法の影響係数は, 以下のようになる. すなわち, その中心が $(\theta, y)$ で, 均一な単位面圧が作 用している要素 $e$ が点 $\left(\theta^{\prime}, y^{\prime}\right)$ のラジアル方向変位 $w$ に与える影響は次式で表される。Eはヤング率, レは ポアソン比である.

$$
\begin{aligned}
w & =\frac{\left(1-\nu^{2}\right)}{\pi E} \\
& \times \iint_{e} \frac{R_{0} \mathrm{~d} \theta \mathrm{d} y}{\sqrt{\left(R_{0} \theta-R_{0} \theta^{\prime}\right)^{2}+\left(y-y^{\prime}\right)^{2}}} \cos \left(\theta-\theta^{\prime}\right)
\end{aligned}
$$

これは Non-Conforming Problem での $x$ の代わり に $R_{0} \theta$ を用いて, かつ円筒面の曲率を考慮して影響 係数の方向修正に $\cos \left(\theta-\theta^{\prime}\right)$ を掛けたものとなって いる。このため，ほぼそのままNon-Conforming Problem での解法が使用でき, 文献 (2)で用いたよう なガウス積分を用いる必要はなくなり, 影響係数とせ ん断応力の両方に対して, 解析積分を用いることがで きる。

$2 \cdot 2$ 事例 文献 (2)の事例 2 (ボールと内輪の接 触)を取上げ，上記手法の検証を行う。 物体 1 : 玉軸受の転動体 (直径 $7.9375 \mathrm{~mm}$ )

物体 $2:$ 玉軸受の内輪軌道面

PCD $34.5 \mathrm{~mm}$, 溝曲率 1.02

接触方向：接触角 $15 \mathrm{deg}$

荷重：9000 N (接触方向)

$2 \cdot 3$ 解析結果 文献 (2)の手法と今回の改良手 法, 並びに FEM 結果を図 3 に示す.

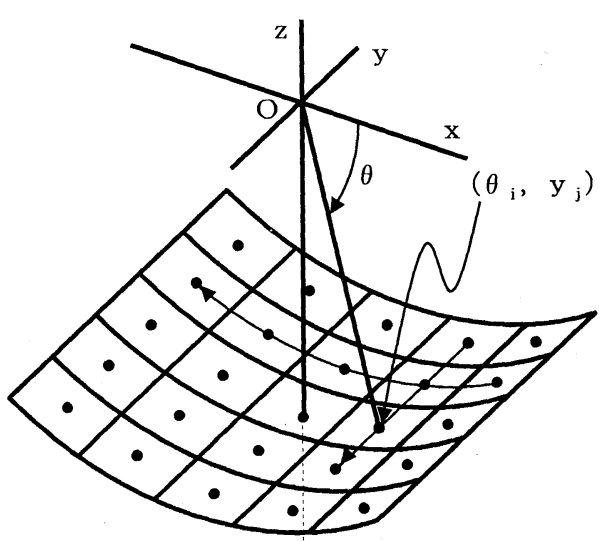

Fig. 2 Cylindrical coordinates 


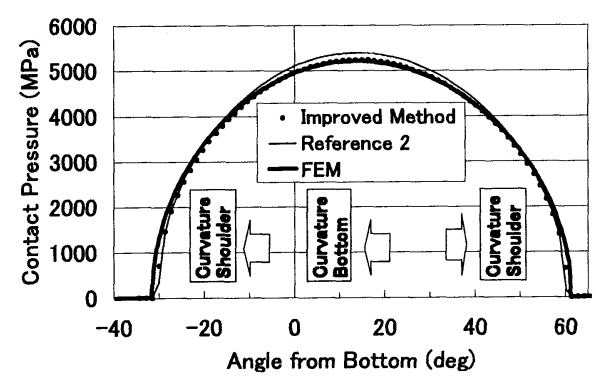

Fig. 3 Contact pressure comparison

3 者とも大きな差はなく,いずれも実用レベルにあ るが, 計算時間では文献 (2) の手法が $197 \mathrm{~s}$, 今回手法 が $112 \mathrm{~s}$ と時間短縮が達成できた (Pentium 4, 3 $\mathrm{GHz})$ 。なお，文献(2)に記載されているように, Non-Conforming Problem として解いた場合は, 図 3 とはかなり異なる面圧分布となり，使用できない.

\section{3. 表面下せん断応力計算}

$3 \cdot 1$ 計算式 本報で扱う応力は, 転がり疲労に 影響する表面下せん断応力 $\tau_{z y}$ である，以下に計算方 法を示す。

その中心が基準円筒上で $\left(\theta^{\prime}, y^{\prime}\right)$ である要素 $e$ が表 面下の深さ $z$ の点 $\mathrm{Q}(\theta, y, z)$ に作用する $\tau_{z y}$ は, Non-Conforming Problem での $\tau_{z y}$ 計算式に式 (1) と同様の修正を加えて, 次式で計算する。この式は解 析的に解が求まるので, これを表面の全要素について 加えて, 点 $\mathrm{Q} の \tau_{z y}$ が求まる.なお $\tau_{z y}$ と表記してい るが, 実際には円筒座標系での $\tau_{z y}$ である.

$$
\begin{aligned}
& \tau_{z y}=\frac{3 z^{2}}{2 \pi} \\
& \times \iint_{e} \frac{\left(y^{\prime}-y\right) R_{0} \mathrm{~d} \theta \mathrm{d} y}{{\sqrt{\left.R_{0} \theta^{\prime}-R_{0} \theta\right)^{2}+\left(y^{\prime}-y\right)^{2}+z^{2}}}^{5}} \cos \left(\theta^{\prime}-\theta\right)
\end{aligned}
$$

$3 \cdot 2$ FEM による検証 $\quad 2 \cdot 2$ 節で取上げた文献 ( 2 ) の事例 2 のモデルに対して, 内輪肩高さを変更し, 鋼球が肩乗り上げを生じた場合の表面下応力 $\tau_{z y} に つ$ いて比較検証を行う (図 4 参照).

内輪は図 4 の MN 軸回り回転体の $90 \mathrm{deg}$ 分を取扱 う. 四面体二次要素を基本とし, 接触部のメッシュは 六面体一次要素を用いた。接触部のメッシュ長は長軸 $30 \mu \mathrm{m}$, 短軸 $10 \mu \mathrm{m}$ の格子状で, 深さ方向は約 $17 \mu \mathrm{m}$ 間隔で $0.6 \mathrm{~mm}$ までを対象としている. 四面体と六 面体の接合部では, 四面体の中間節点を多点拘束によ り拘束した。節点数は 1438 604, 要素数は 1159822 であり，13 台のパソコンによる並列計算を行った。溝
触角 $15 \mathrm{deg}$ 方向へ $9000 \mathrm{~N}$ の荷重を負荷

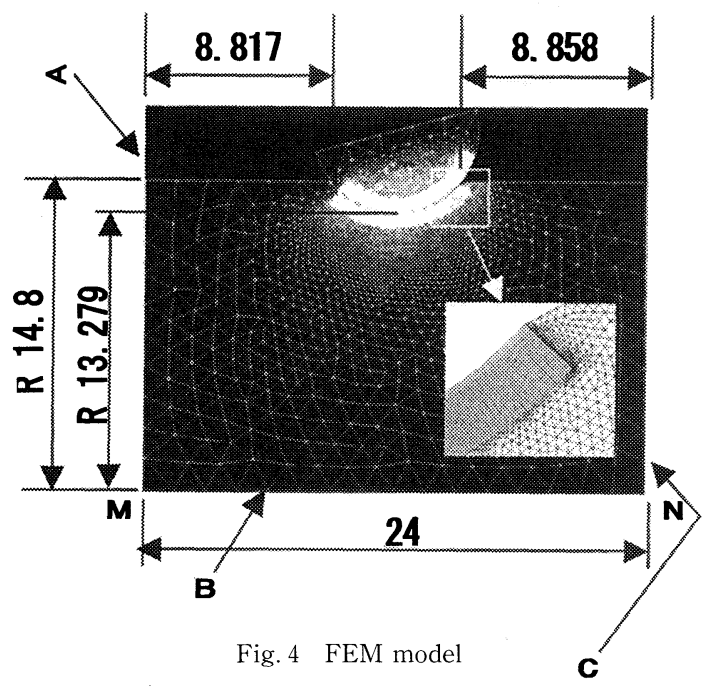

肩には $0.2 \mathrm{~mm}$ の直線チャンファがあり，転走面での 肩高さは R 14.6 である.

境界条件：A，C 面上節点を全方向に固定

$\mathrm{B}$ 面上節点を紙面上下方向に固定 紙面上節点の紙面垂直方向変位を拘束

荷重条件：球の切断面と平行な剛体面を配置し，剛体 面上をボールが移動しないように拘束しな がら, 剛体面の荷重制御により接触角 15 $\operatorname{deg}$ 方向へ $9000 \mathrm{~N}$ の荷重を負荷

$\tau_{z y}$ の計算結果を図 5,6 に示す. 図 5,6 は内輪肩位 置付近の $\tau_{z y}$ が最大となる位置(接触点位置から約 32 $\operatorname{deg}$ の位置)で接触だ円長軸に垂直な断面で切り, 断 面のせん断応力分布をコンタ表示したものであり, 図 5 はFEM, 図 6 は著者らの手法である. 著者らの手 法では, 面圧メッシュ (後述) は $\theta=25 \sim 125 \mathrm{deg}, y=$ $\pm 0.3 \mathrm{~mm}$ の領域を, $N A=71, N B=51, \Delta F M=0.1$, $D I V=5$ で分割したものを使用した，応力メッシュは $\theta$ 方向に $0.2 \mathrm{deg}, y$ 方向に $0.002 \mathrm{~m}$, 深さ方向に $0.01 \mathrm{~mm}$ の均一刻み幅のものを使用した。 $y$ 軸は接 触だ円短軸方向である. 両者の值はおおむね一致して おり, 上記手法の妥当性が確認できた。 なお, FEM では本来零であるべき表面に少しせん断応力が発生し ているが, 接触計算の誤差と考える.

\section{4. 転がり疲労寿命}

4 •1 概要 文献 (8)では, 転走面をスライスし て各スライス片の寿命を取扱い, ころ軸受について寿 命試験結果との比較を行った。ここではその手法を玉 


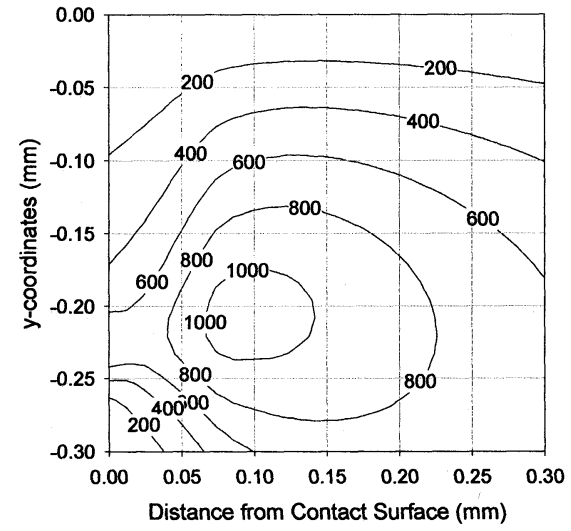

Fig. $5 \tau_{z y}$ contour plot by FEM

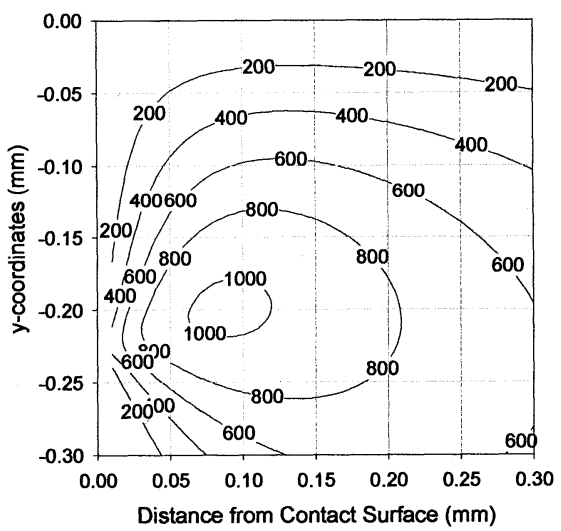

Fig. $6 \tau_{z y}$ contour plot by authors' method

軸受に適用する。

文献 ( 8 )の手法の適用に際して, 以下の点が異なる が, 基本的な違いはない. (1)座標系を直交座標系から 円筒座標系に変更する。 (2)軸受寿命理論の係数 $e$ が 異なる。 (3)各スライス片で軌道面円周長さ $l$ が異な る.

$4 \cdot 2$ 玉軸受寿命理論 図 7 の綾目ハッチングで 示すように表面下体積をスライスする，各スライス片 は図の断面をもつ回転体である. 図 7 ではスライス片 が台形になっているが，計算上取扱う領域は深さ方向 に非常に浅い領域であるため, 矩形とみなしても問題 ない. 以下の寿命計算で用いるせん断応力の振幅 $\tau_{0}$ は, 図のメッシュを紙面に垂直な方向に移動させてメ ッシュを $3 \mathrm{D}$ 化し，紙面から外れる方向に $\tau_{z y}$ の最大 値, 最小值を求めれば, それが鋼球が転がることによ って生じる応力振幅 $\tau_{0}$ である.

LP 理論では，次式にて寿命を算出する.

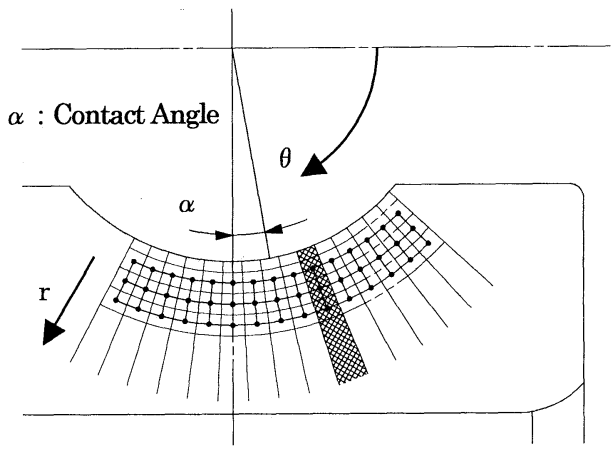

Fig. 7 Mesh for $\tau_{z y}$ calculation

$$
\log \frac{1}{S} \propto F_{\left(\tau_{0}, N, z_{0}\right)} V
$$

ただし，

$F \propto \frac{\tau_{0}^{c} N^{e}}{z_{0}^{h}}$

$V \propto a z_{0} l$

$S:$ 材料が $N$ の繰返し荷重に耐えられる確率

$\tau_{0}:$ 最大せん断応力振幅

$z_{0}$ : 最大せん断応力振幅が生じる深さ

$a ：$ 接触だ円長軸の半径

$l:$ 軌道面の円周長さ

$c, e, h$ は実験で決定された指数で，玉軸受の場合 は，それぞれ $31 / 3,10 / 9,7 / 3$ を用いる。

全体の寿命は次式にて求める，以下では，スライス 片に関するものに添字 $i$ を付けている.

$$
\log \frac{1}{S}=\sum_{i=1}^{n} \log \frac{1}{\Delta S_{i}}
$$

$\Delta S_{i}$ : 個久の分割体積の残存確率 $(i=1 \sim n)$

文献 ( 8 )で導いた寿命計算手法のように, 各スライ ス片に以下の式を適用する. 文献 $(8)$ と異なり, 式 (6)の $l$ には個々のスライス片の值を用いている(4・1 節の(3)対応).

$$
\begin{aligned}
& F_{i} \propto \frac{\tau_{0 i}^{c} N^{e}}{z_{0 i}^{h}} . \\
& V_{i} \propto a_{i} z_{0 i} l_{i}
\end{aligned}
$$

式 $(5)$ ，（6）より，寿命計算式は次式のようになる.

$$
\begin{aligned}
L_{i} & =A_{1}\left(\frac{z_{0 i}^{h-1}}{\tau_{0 i}^{c} a_{i} l_{i}}\right)^{1 / e} \\
& =A_{1} \cdot \tau_{0 i}^{-c / e} \cdot z_{0 i}^{(h-1) / e} \cdot\left(a_{i} l_{i}\right)^{-1 / e}
\end{aligned}
$$

式( 7 )で各分割片での寿命が決定されるが, 本報で は $A_{1}$ は決定せず, 寿命比として算出する. 次式にて, スライス片の寿命を合成して, 全体の寿命を求める.

$$
\frac{1}{L}=\left[\left(\frac{1}{L_{1}}\right)^{e}+\left(\frac{1}{L_{2}}\right)^{e}+\cdots+\left(\frac{1}{L_{n}}\right)^{e}\right]^{1 / e} \cdots
$$


Table 1 Samples and life test result

\begin{tabular}{|l|r|r|r|}
\hline & \multicolumn{1}{|c|}{ No.1 } & \multicolumn{1}{c|}{ No.2 } & \multicolumn{1}{c|}{ No.3 } \\
\hline Outer Diameter & $\phi 40.8$ & $\phi 37.8$ & $\phi 37.388$ \\
\hline Race Width (B) & \multicolumn{1}{|c|}{3.726} & 3.917 & 2.798 \\
\hline $2^{(*)}$ & \multicolumn{3}{|c|}{5.596} \\
\hline Number of Inner-Ring Early Damage & $18 / 20$ & $11 / 20$ & $9 / 10$ \\
\hline Sample Number & 1.723 & 0.7746 & 1.031 \\
\hline $\mathrm{e}$ & 523 & 76.51 & 24.76 \\
\hline L10 & 1561 & 870.8 & 153.8 \\
\hline L50 & &
\end{tabular}

(*) Semi-Major Dia. of Contact Ellipse by Hertzian Theory

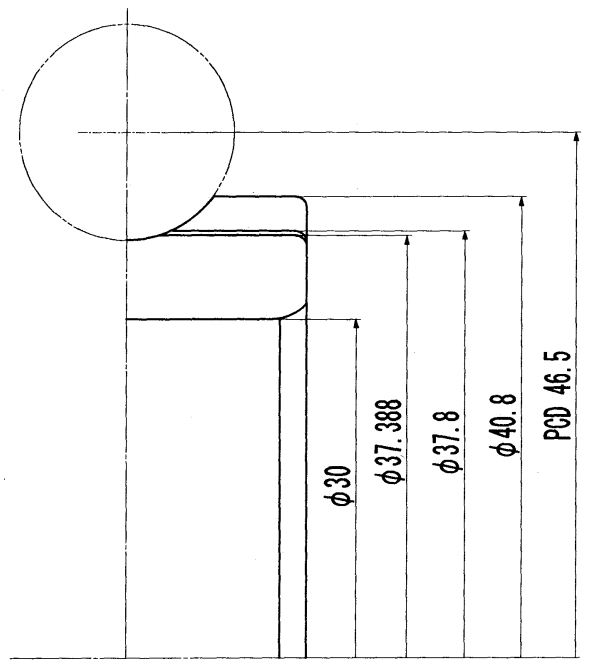

Fig. 8 Sample for bearing life test

\section{5. 軸受寿命試験}

$5 \cdot 1$ 供試サンプル 上記寿命予測手法を検証す るため, 肩乗り上げが生じた状態での耐久試験を実施 した，肩乗り上げを生じさせるには，(1)接触荷重を大 きくする, (2)接触角を大きくする, (3)肩高さを小さく する，の三とおりが考えられる。ここでは試験機の構 造, 強度の問題から, (3)の方法を採用した。

試験に供した軸受はNTN (株) 製深溝玉軸受 6206 で, 表 1 に示す軸受内輪外径を変えたサンプル 3 種を 製作した。参考までに, Hertzの接触理論から算出し た接触だ円の長さ $(2 a)$ と溝幅 $(B)$ を併記した。軸受 内輪のプロフィールを図 8 に示す.

なお，転走面と内輪外径の間のチャンファは手ラッ プで仕上げており，0.1 mm 以下である.チャンファ 形状は図 8 の内輪断面で見て, 内輪溝と内輪外径の交 点から溝深さ方向と内輪軸方向に所定の量だけ離れた 点を結ぶ直線形状である.

$5 \cdot 2$ 試験結果上記サンプルを図 9 の試験装置 に掛けて, 表 2 の条件で実施した耐久試験の結果のう
Table 2 Rolling fatigue test condition

\begin{tabular}{|l|l|}
\hline \multicolumn{1}{|c|}{ Items } & \multicolumn{1}{c|}{ Conditions } \\
\hline Radial Load & $6.86 \mathrm{kN}[700 \mathrm{kgf}]$ / 1Bearing \\
\hline Shaft Rotating Speed & $2000 \mathrm{r} / \mathrm{min}$. \\
\hline Lubrication & $\begin{array}{l}\text { Circulating Lubrication } \\
\text { Turbine Oil VG56 }\end{array}$ \\
\hline $\begin{array}{l}\text { Bearing Radial Clearance } \\
\text { (After Fitting) }\end{array}$ & $0.02 \mathrm{~mm}$ \\
\hline
\end{tabular}

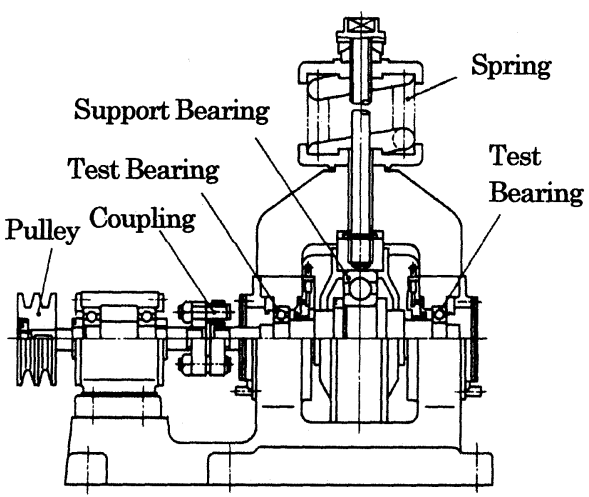

Fig. 9 Endurance test rig

ち, 内輪先行はく離したものの寿命 L 10，L 50 を表 1 に併記した. $e$ はワイブルスロープ係数である.

\section{6. 寿 命 計 算}

$6 \cdot 1$ 計算前提 耐久試験では純ラジアル荷重が 負荷されることを狙って試験を行っているが, 軸受組 付けの際に軸受内輪溝中心と外輪溝中心が軸方向にず れたり，あるいは軸受耐久試験中の軸方向振動や軸の たわみの影響により若干の接触角が生じていると考え るのが妥当である.内外輪の溝中心が軸方向へ 0.1 $\mathrm{mm}$ ずれると接触角は約 $7.5 \mathrm{deg}, 0.2 \mathrm{~mm}$ 移動する と約 $14.7 \mathrm{deg}$ となる. このため, 以下の検討は接触 角 $\alpha$ を $0 \mathrm{deg}$ と $10 \mathrm{deg}$ で行う.

寿命の大部分は最大荷重の転動体との接触で決まる ため, 本報では最大荷重を負荷されるボールと内輪の 接触について取扱うことにする、転動体に負荷される 最大荷重は文献 (11)の手法により算出した. 試験に供 したサンプルのラジアルすきまは $20 \mu \mathrm{m}$ であり, 接触 角が $0 \mathrm{deg}$ のきは $3557.85 \mathrm{~N}\{362.8 \mathrm{kgf}\}, 10 \mathrm{deg}$ の場合は $3481.36 \mathrm{~N}\{355.0 \mathrm{kgf}\}$ であった。接触角 10 $\operatorname{deg}$ の場合は，付録に示す手法でラジアルすきまを算 出した。両荷重の差は2\%であり, ほぼ同じである。 本報ではこの差は無視できると考え, 接触角 $10 \mathrm{deg}$ の場合も $0 \mathrm{deg}$ と同じ荷重値 $3557.85 \mathrm{~N}$ \{362.8 kgf $\}$ を接触角方向へ負荷する. 
$6 \cdot 2$ 面圧メッシュ 面圧計算用のメッシュを図 10 に示す. 図 10 は基準面の円筒を展開したものであ り, 肩乗り上げ時の面圧を表現するために, 肩部のメ ッシュ間隔を狭くした不等間隔のメッシュとなってい る.メッシュは $\theta$ 方向分割数を $N A, y$ 方向分割数を $N B$ として, $\theta$ 方向には応力集中箇所の両側に再分割 領域 $\Delta F M$ を設け, その中央に向かうにつれ等比級数 的に間隔を狭くする方式で分割数 $D I V$ の分割をす る.これにより面圧メッシュは, $N A=24, N B=24$, $F M=74.5 \mathrm{deg}, \Delta F M=0.1 \mathrm{deg}, D I V=5$ のよう 表現できる。本例では角度範囲で $80 \mathrm{deg}$ (接触点位置 から片側 $40 \mathrm{deg}$ )，接触だ円短軸方向 ( $y$ 方向) $0.6 \mathrm{~mm}$ とし $, N A=81, N B=71, \Delta F M=0.1, D I V=7$ とし ている. サンプルごとに肩の位置が変わるため, これ に対応して FMの值を変えている.

$6 \cdot 3$ 接触問題としての位置付け 肩乗り上げを 生じる場合は一般に Conforming Problem となるが, 今回の試験では内輪外径を小さくして乗り上げを生じ させているため, 顕著な Conforming Problem とは なっていない, サンプル No.1について, Non-Con-

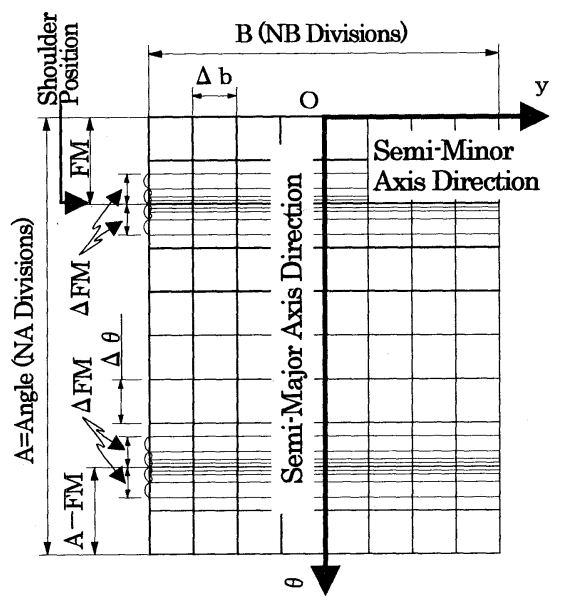

Fig. 10 Mesh for pressure calculation

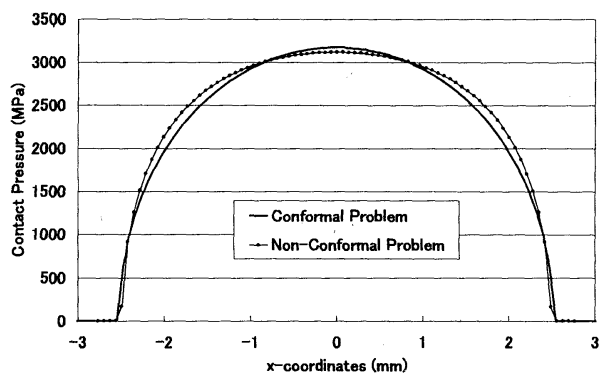

Fig. 11 Comparison of pressure distribution

forming Problemとして解いた場合(1)と Conforming Problem として解いた場合(著者らの手法)を比較 すると図 11 のようであり, 若干の差が出る程度であ る.このため, Non-Conforming Problemとして解 いても近似解が得られるレベルと推定される。なお，

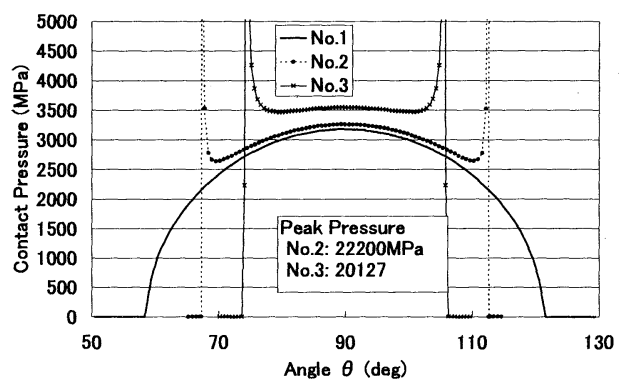

(a) $\alpha=0 \mathrm{deg}$

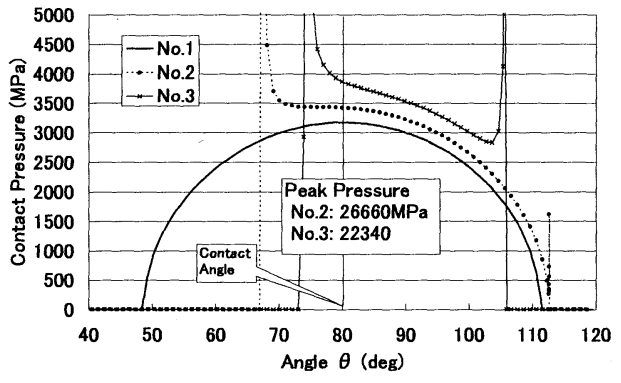

(b) $\alpha=10 \mathrm{deg}$

Fig. 12 Contact pressure (cross section of $y=0$ )

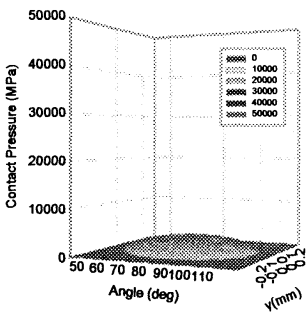

(a) No.1

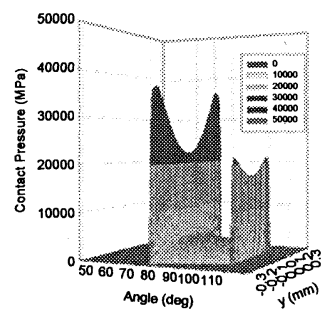

(c) No. 3

Fig. $133 \mathrm{D}$ contact pressure $(\alpha=10 \mathrm{deg})$

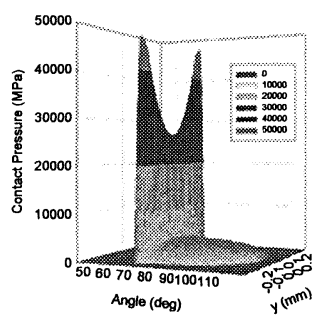

(b) No. 2 
Conforming Problem の場合, 横軸には円筒面を平面 に投影したときの距離を使用している.

$\mathbf{6} \cdot \mathbf{4}$ 面圧計算 接触角が $10 \mathrm{deg}$ の場合の接触だ 円短軸の中央位置で軸に直角な断面で切断したときの 面圧分布を図 12 に, $3 \mathrm{D}$ 面圧表示を図 13 に示す.

ピーク面圧はNo. 2 より No. 3 のほうが小さくなっ ている.これはNo. 3 では接触領域が内輪肩部チャン ファへ，かなりはみだしてしまうことにより，面圧が

Table 3 Mesh for shear stress calculation

\begin{tabular}{|c|c|c|c|c|c|c|}
\hline & \multicolumn{2}{|c|}{$\theta$ (deg) } & \multicolumn{2}{c|}{$y(\mathrm{~mm})$} & \multicolumn{2}{c|}{$z(\mathrm{~mm})$} \\
\cline { 2 - 7 } & Range & $\begin{array}{c}\text { Element } \\
\text { Size }\end{array}$ & Range & $\begin{array}{c}\text { Element } \\
\text { Size }\end{array}$ & Range & $\begin{array}{c}\text { Element } \\
\text { Size }\end{array}$ \\
\hline Mesh I & \pm 40 & 0.2 & $-0.3 \sim 0$ & 0.002 & $0 \sim 0.3$ & 0.01 \\
\hline Mesh II & \pm 40 & 0.5 & $-0.3 \sim 0$ & 0.002 & $0 \sim 0.15$ & 0.001 \\
\hline
\end{tabular}

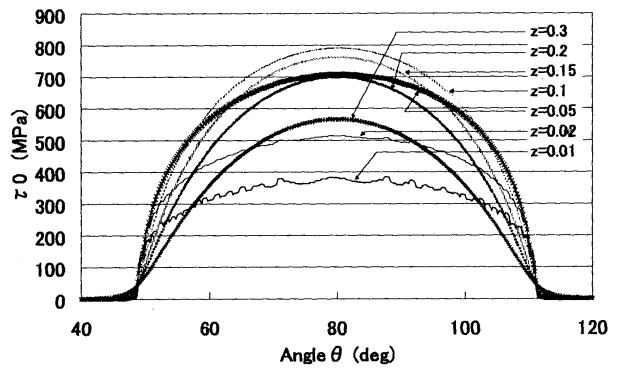

(a) No.1

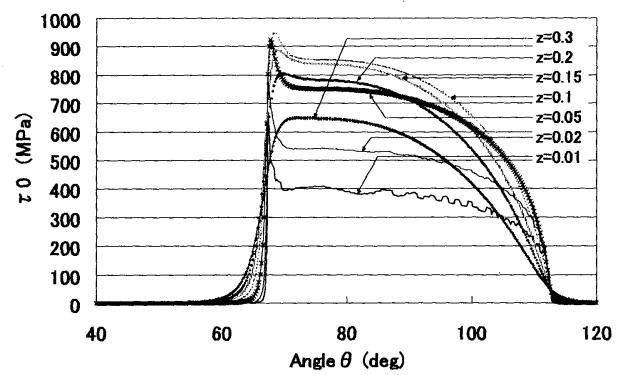

(b) No.2

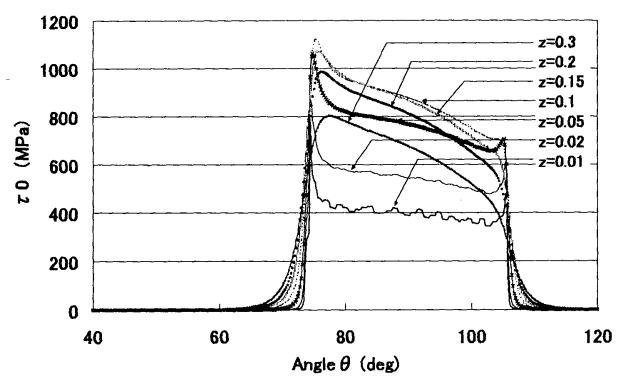

(c) No. 3

Fig. 14 Shear stress amplitude $(\alpha=10 \mathrm{deg})$
低下すると考えられる。

6・5 せん断応カメッシュ せん断応力計算は概 略傾向を知るための応力メッシュI と寿命計算に使用 する応力メッシュIIの 2 種類のメッシュを使用して行 った. $\theta$ 方向には接触点の $\pm 40 \mathrm{deg}$ の領域について 計算した。それぞれの特徴を表 3 に示す。メッシュII はメッシュIより $\theta$ 方向に粗くなっているが， $\theta$ 方向 の応力ピーク位置近傍 (No. 2 は 67.5 69.0 deg, No. 3 は 74.5〜 76.0 deg と 104〜105.5 degの範囲)では $0.1 \mathrm{deg}$ 刻みとし，メッシュ I 以上に細かくした。

6・6 せん断応力計算 表 3 のメッシュIによる 各サンプルの $\tau_{0}$ 計算結果を図 14 に示す.

深さが浅い領域 $(z=0.01)$ においては，いずれの場 合も若干の波打ち現象が現れているが，応力值が小さ いため寿命計算結果に大きな影響を及ぼすものではな (.

せん断応力計算から得られた $\tau_{0}$ とその位置の $z_{0}$ お よび $\theta$ の値を表 4 にまとめる(メッシュ II を使用).

$6 \cdot 7$ 寿命計算 これらの結果を用いて寿命計算 を行った. No.1の寿命との比についての結果を図 15 に示す.

実験と計算の傾向は概略一致しているといえるが, 接触角 $0 \mathrm{deg}$ では実験とのかい離が大きい，接触角 $10 \mathrm{deg}$ を仮定すると比較的一致するが，それでも No. 3 では，計算のほうが寿命が長く算出されている。こ の原因としては, 文献 $(8)$ のころ軸受のときもそうで あったように，エッジロードによる高面圧が潤滑状態

Table 4 Maximum shear stress and $z_{0}$

\begin{tabular}{|c|c|c|c|c|c|c|c|}
\hline \multicolumn{2}{|c|}{} & \multicolumn{3}{|c|}{$\alpha=0 \mathrm{deg}$} & \multicolumn{3}{c|}{$\alpha=10 \mathrm{deg}$} \\
\cline { 2 - 8 } \multicolumn{2}{c|}{} & No.1 & No.2 & No.3 & No.1 & No.2 & No.3 \\
\hline \multirow{4}{*}{ Center } & $\tau_{0}(\mathrm{MPa})$ & 792 & 812 & 886 & 791 & 854 & 971 \\
\cline { 2 - 8 } & $z_{0}(\mathrm{~mm})$ & 0.104 & 0.107 & 0.116 & 0.104 & 0.112 & 0.127 \\
\cline { 2 - 8 } & $\theta(\mathrm{deg})$ & 90 & 90 & 90 & 80 & 80 & 80 \\
\hline \multirow{3}{*}{ Edge } & $\tau_{0}(\mathrm{MPa})$ & - & 674 & 943 & - & 956 & 1123 \\
\cline { 2 - 8 } & $z_{0}(\mathrm{~mm})$ & - & 0.069 & 0.081 & - & 0.082 & 0.093 \\
\cline { 2 - 8 } & $\theta(\mathrm{deg})$ & - & 68.3 & 75.2 & - & 68.2 & 75.2 \\
\hline
\end{tabular}

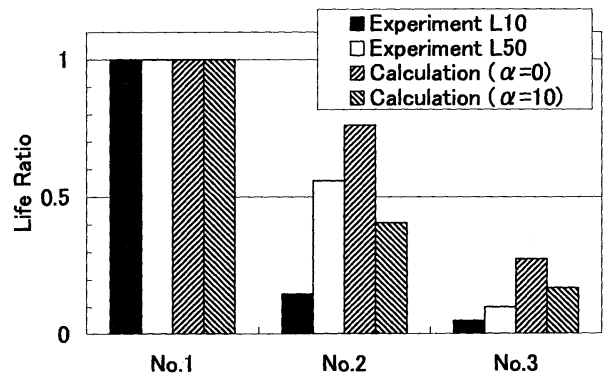

Fig. 15 Comparison of experiment and calculation 


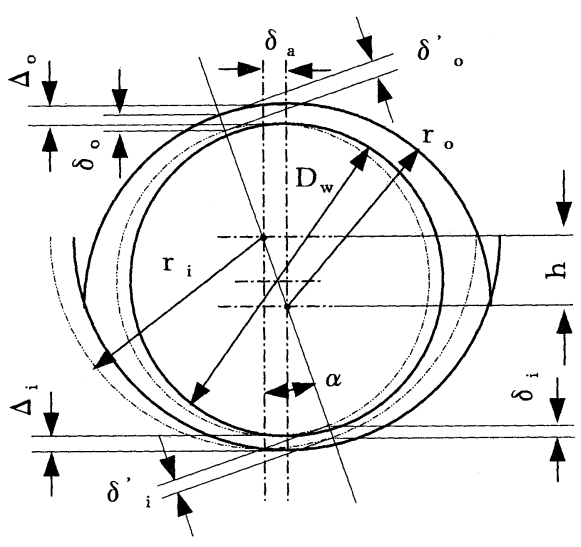

Fig. 16 Cross section of ball bearing

の悪化を招き寿命低下することに加えて, 今回はチャ ンファ部の表面粗さが転走面より劣ることにより実寿 命の低下をもたらしている可能性も推測される。

\section{7. あと がき}

Conforming Problemのうち接触領域が円筒形状 とみなせるものに対して, 文献 $(2)$ の計算方法の改良 を行い, 計算速度の向上を図った。また，この改良手 法を用いた場合, せん断応力が FEMの結果と一致す ることを確認した。

上記改良手法を用いて，肩乗り上げが生じたときの 玉軸受の表面下せん断応力分布を算出し，これを用い て文献（８）の寿命計算手法の適用を行った。実験結果 との比較から，本手法の寿命計算值は実寿命の傾向を とらえてはいるが，エッジロードがきつい場合，計算 寿命が長くなり，完全な一致を見ることはできなかった。

エッジロードが大きい場合に実験結果と一致しない 原因としては, 実現象では高面圧による油膜形成不良 により寿命低下することや肩部チャンファの表面粗さ が転走面より劣ることが考えられる. 本手法は従来の 面圧べースの手法より優れていると考えるが, さらに 実験との一致度を向上させるためには, 潤滑状態を考 慮した寿命モデルの構築が必要と考える.

本報では FEM 解析部分を芋生が，それ以外の部分 を長谷が担当した。

\section{付 録}

接触角が付いた場合のラジアルすきま算出方法を以 下に述べる。

図 16 は，接触角が零の初期状態から，内輪が軸方向 へ移動し，接触角が $\alpha$ になった場合を表している。 接触角が零のとき次式の関係がある.

$$
r_{i}+r_{o}-D_{w}-h=\Delta_{i}+\Delta_{o}
$$

ラジアルすきま $\Delta r$ は以下の式で与えられる.

$$
\Delta r=2\left(\Delta_{i}+\Delta_{o}\right)
$$

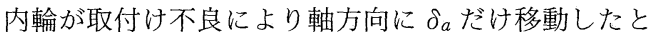
きのラジアルすきま $\delta_{r}$ は次式で求められる。なお, プライムは接触角方向の変数であることを表す。

$\delta_{r}=2\left(\delta_{i}+\delta_{o}\right)$

ここで

$$
\begin{gathered}
\delta_{i}+\delta_{o}=\left(\delta_{i}^{\prime}+\delta_{o}^{\prime}\right) \cos \alpha \\
=\left(r_{i}+r_{o}-D_{w}-h^{\prime}\right) .
\end{gathered}
$$

$h^{\prime}=h / \cos \alpha$

\section{文献}

(1) Hartnett, M. J., The Analysis of Contact Stresses in Rolling Element Bearings, Transactions of the ASME Journal of Lubrication Technology, Vol. 101 (1979), pp. 105-109.

(2) Nagatani, H. and Imou, A., Contact Pressure Analysis in Conforming Problem, Transactions of the Japan Society of Mechanical Engineers, Series C, Vol. 73, No. 731 (2007), pp. 232-240.

(3) Itoh, S. and Sugiura, I., Investigation of Optimum Crowning in Line Contact Cylinder to Cylinder Type Rolling Contact Fatigue Test Rig, NTN Technical Review, No. 48 (1982), pp. 18-26.

(4) Fujiwara, H. and Kawase, T., Logarithmic Profile of Rollers in Roller Bearing and Optimization of the Profile, Transactions of the Japan Society of Mechanical Engineers, Series C, Vol.72, No. 721 (2006), pp. 338-345.

(5) Harada, M., Kamamoto, S. and Fujiwara, Y., Roller Bearing Crowning Profile Considering Subsurface Stress (in Japanese), Tribology Congress 2000-5, (2000), C 6, pp. 171-172.

(6) Ioannides, E. and Harris, T. A., A New Fatigue Life Model for Rolling Bearings, Transactions of the ASME, Journal of Tribology, Vol. 107 (1985), pp. 367378.

(7) Lundberg, G. and Palmgren, A., Dynamic Capacity of Rolling Bearings, Acta Polytechnica, Mechnical Engineering Series, Vol. 1, No. 3 (1947), and Lundberg, G. and Palmgren, A., Dynamic Capacity of Roller Bearings, Acta Polytechnica, Mechnical Engineering Series, Vol. 2, No. 4 (1952).

(8) Nagatani, H., Fatigue Life Estimation for Roller Bearings at Edge Load Occurrence, Transactions of the Japan Society of Mechanical Engineers, Series C, Vol. 74, No. 742 (2008), pp. 1609-1616.

(9) Nagatani, H., Contact Pressure and Shear Stress Analysis with Quadrangle Linear Element, Transactions of the Japan Society of Mechanical Engineers, Series C, Vol. 73, No. 732 (2007), pp. 227-234.

(10) Johnson, K. L., Contact Mechanics, (1985), p. 50, Cambridge Univ. Press.

(11) Jones, A. B., A General Theory for Elastically Constrained Ball and Radial Roller Bearings Under Arbitrary Load and Speed Conditions, Transactions of the ASME, Journal of the Basic Engineering, Vol. 82, No. 1 (1960), pp. 309-320. 